\title{
Cytogenotoxic Anomalities in the Pest Grasshopper Zonocerus Variegatus L. (Orthoptera: Pyrgomorphidae) on Treatment with Aqueous Extract from Tephrosia Vogelii Hook F (Fabaceae)
}

\author{
Seino $\mathrm{RA}^{1-3^{*}}$, Achang $\mathrm{Ky}^{2}$, Atonleu $\mathrm{MS}^{3}$
}

${ }^{1}$ Department of Animal Biology, Faculty of Science, the University of Bamenda, P.O. Box 39, Bambili - Bamenda, Cameroon

${ }^{2}$ Phytobiotechnology Research Foundation Institute, Bamenda, P.O. Box 921, Bamenda, Cameroon

${ }^{3}$ Department of Animal Biology, Faculty of Science, the University of Dschang, BP 57, Dschang, Cameroon

The results of cytogenetic effects of extracts from the leaves of Tephrosia vogelii by using the meiotic process in the African pest grasshopper Zonocerus variegatus is presented in this paper. Zonocerus variegatus (Orthoptera: Pyrgomorphidae) is the main grasshopper pest in humid forest areas of West and Central Africa and is reported to be the third most important insect pest in the humid forest zone of Cameroon. The plant $T$. vogelii, is a soft woody branching small tree $(0.5$ to $4 \mathrm{~m}$ tall) with dense foliage that is commonly planted in farms in the North West Region of Cameroon is a known repellant of Z. variegatus. In Cameroon and some other African countries, T. vogelii is used for several ethno-medical and traditional veterinary practices, as well as a soil enrichment and pest control agent. So far, no information on the cytogenotoxic activity of $T$. vogelii exists in available literature. The present study therefore was aimed to evaluate the cytogenotoxic effects of extracts from the leaves of $T$. vogelii by using the meiotic process in the African pest grasshopper Zonocerus variegatus. Fifth instar nymphs of $Z$. variegatus were treated with $0.1 \mathrm{ml}$ of different concentrations $(0 \mu \mathrm{g} / \mathrm{l}, 5 \mu \mathrm{g} / \mathrm{l}$ and $10 \mu \mathrm{g} / \mathrm{l})$ of aqueous extracts prepared from $100 \mathrm{gm}$ of powdered leaves of T. vogelii. The extract induced several prominent chromosomal aberrations in the germ-line cells of Z. variegatus that included: Laggards, Disturbed Metaphases and Anaphases, bridges sticky chromosomes and vagrant chromosomes. The formation of sticky chromosomes, laggards and bridges were the most numerous aberrations recorded. Chromosome breaks, disturbed spindles, chromosome loss were rare. Pictures of these abnormalities are presented and their implications on the meiotic process in $Z$. variegatus are discussed. The findings from this study suggest that the leaves of $T$. vogelii possess strong cytogenotoxic properties to the germ-line cells of $Z$. variegatus.

Keywords: Aqueous extract, meiotic chromosome abnormalities, Tephrosia vogelii, Zonocerus variegatus.

Copyright @ 2020: This is an open-access article distributed under the terms of the Creative Commons Attribution license which permits unrestricted use, distribution, and reproduction in any medium for non-commercial use (NonCommercial, or CC-BY-NC) provided the original author and source are credited

\section{INTRODUCTION}

Zonocerus variegatus is an aposematically coloured African grasshopper that sequesters a toxic chemical from plants and produces a foul smelling liquid when disturbed [1]. It belongs to the subfamily Pyrgomorphinae in the family Pyrgomorphidae of the order Orthoptera. It is found in manmade environments where it lives in dense groups and thrives at the expense of agricultural activity in West, Central and East Africa. It is currently the most important grasshopper pest in several parts Cameroon, Cote d'Ivoire, Ghana, Benin, Uganda, Senegal, Sierra Leone, and Burkina Faso. It is polyphagous and feeds on a wide range of food and cash crops that include cassava, citrus fruits, banana, coffee, cowpea, yams, soybeans and maize [1-5]. Since Zonocerus variegatus has an obnoxious behaviour, several control measures have been developed. Some of these measures include the effective but very laborious method of digging out egg pods [6], the use of entomopathogens such as the conidia of the fungus species Metarhizium flavoviride and Beauveria bassiana [7, 8], Charletonia cameroonensis [9] and the use of broad spectrum insecticides (Cypermethrin, Gamalin and Sumithion) $[6,10]$. Synthetic insecticides though fast acting and effective, are known to be out of the reach of the common farmer by virtue of their costs, cause environmental pollution and health hazards to warm blooded animals, destruction of natural pest control organisms and introduction of possible resistance of the insects to insecticide action. For these and many other reasons, the search for effective natural insecticides has intensified. Natural insecticides are known to have less impact on beneficial and non-target insects than 
conventional pesticides [11], low toxicity to warm blooded animals, have a relatively long residual action, and they are cheap to acquire since they are locally available. In addition, they are easy to apply and most of all they are friendly to the environment. Indeed the use of pesticidal plants has been a major component of pest management in sub-Saharan Africa for generations, and their use continues to this day [12-18]. The control of the grasshopper pest $Z$. variegatus has therefore generated interest for the search of a natural insecticide.

More than 2000 species of plants are known to possessed insecticidal activities [11]. Despite this only a few have been scientifically evaluated. This study was therefore designed to screen out $T$. vogelii against the pest grasshopper Z. variegatus.

Tephrosia vogelii is a common evergreen shrub that grows to about $4 \mathrm{~m}$ tall and has been used for generations for soil enrichment, and pest control in several African countries [19]. This plant is a potential source of rotenone which is an important non-residual insecticide and Tephrosin which is the main active compound useful in killing fish. The plant also possess deguilin with high levels of bioactivity against insects as well as several flavonoids such as rotenone, sarcolobine and $\alpha$-toxicarol that boost bioactivity against insects [19, 20]. Crude extract from leaves of Tephrosia vogelii is potentially used to control ticks and worms in animals as well as field control of insect pests [21-23]. However, most of the research on the insecticidal effect of $T$. vogelii has been directed to beetles (Coleoptera) even though this natural pesticidal plant has been publicized for years as an alternative to synthetic insecticide in the permanent management of pests including grasshoppers [24]. This study was therefore conducted to evaluate the potentials of $T$. vogelii to induce cytogenotoxic aberrations in $Z$. variegatus.

\section{MATERIALS AND METHODS}

The plant $T$. vogelii used in this study was collected from the demonstration farm of the Institute of Agricultural Research for Development (IRAD) located at Babungo, Ngoketungia Division in the North West Region of Cameroon. Taxonomic identification and authentication was carried out by Botanists at the centre for Agronomic Research (IRAD) Bambui. Leaves of the plant were air-dried at room temperature to a constant weight and ground to powder $\mathrm{m}$. One hundred grams $(100 \mathrm{~g})$ of powder was soaked in one litre (1L) of distilled water and stirred vigorously at intervals for 48 hours. Filtration was carried out with the help of a Whatman filter paper. The filtrate was concentrated at $45^{\circ} \mathrm{C}$ in a hot oven for 48 hours. The aqueous solution obtained $43.8 \%$ of total dry weight of the leaves of $T$. vogelii, was preserved in well screwed and airtight vials and stored in a refrigerator $\left(4^{0} \mathrm{C}\right)$ until needed. A pilot study established the $\mathrm{LD}_{50}$ of $T$. vogelii for the grasshopper $Z$. variegatus at $17.82 \mu \mathrm{g} / \mathrm{ml}$ and it was observed that at concentration $10 \mu \mathrm{g} / \mathrm{l}$, none of the insects died after 48 hours incubation. Thus, the stock solution of $43.8 \%$ was then used to prepare by dilution with distilled water, $0 \mu \mathrm{g} / 1,5 \mu \mathrm{g} / \mathrm{l}$ and $10 \mu \mathrm{g} / \mathrm{l})$ solutions used in this study.

Thirty (30) fifth instar male $Z$. variegatus collected on the Campus of The University of Bamenda, in the North West Region of Cameroon. They were kept in the Applied Ecology Laboratory of the Department of Animal Biology, Faculty of Science, the University of Dschang, Cameroon, for three days to acclimatize before the start of the experiment. The grasshoppers were placed into three groups of ten and labelled A, B and C. Individuals in these groups were respectively injected $0.01 \mathrm{ml}$ of $0 \mu \mathrm{g} / \mathrm{l}, 5 \mu \mathrm{g} / \mathrm{l}$, and $10 \mu \mathrm{g} / \mathrm{l}$, of aqueous T. vogelii leaf extract. Individuals in group A were injected with distilled water $(0 \mu \mathrm{g} / \mathrm{l}$ of $T$. vogelii leaf extract) and used as the control. The treated grasshoppers were incubated in the laboratory for 72 hours, killed in chloroform and dissected for the testes in insect saline $(68 \%$ Sodium Chloride). The testes were placed in labelled vials containing Canoy's solution (3:1 Ethanol: Acetic acid fixative) and stored in a refrigerator at $4^{\circ} \mathrm{C}$ until needed. Chromosome smears from these testes were prepared using the Lactic - Propionic Orcein Squash Technique [25] and were examined using a Fisher binocular microscope using the $10 \mathrm{X}$ and $40 \mathrm{X}$ objectives. The number and types of chromosome aberrations were recorded from 743 cells examined. Photographs of these chromosome aberrations were made using an Itel A51 phone mounted with a 5.0 pixa lens. The data collected was subjected to the One Way ANOVA test level to test for significant differences at $\mathrm{p}<0.05$ between meiotic chromosome abnormalities induced by the different extracts tested.

\section{RESULTS AND DISCUSSION}

Control of grasshoppers and field insect pest in Cameroon has been essentially with synthetic insecticides. Over 20 insecticides are used by Cameroonian farmers composed of a broad range of active ingredients. The principal ones include Cypermethrin and Chlorpyrifos [26, 27]. These insecticides are expensive and are often out of the reach of most local farmers. Persistent use of these insecticides (against grasshoppers) provides an effective means of control. Synthetic insecticides have been shown to be unfriendly to the environment because they kill indiscriminately and including natural control organisms [28]. They are known to have the ability to cause a large number of negative health effects that include dermatological, gastrointestinal, neurological, carcinogenic, respiratory, reproductive, and endocrine effects [29-31]. More so, most Cameroonian farmers lack the technical know-how for their application. For these reasons and more, there has been growing interest for the development of biological control and the use of locally available plant bio pesticides against Acridid pest. Available evidence points to $T$. vogelii as a 
potential bio insecticide. The crude extracts of this plant have been efficient against several beetle species [32, 33].

Individuals of $Z$. variegatus in the control group, showed normal meiotic stages that included Prophase -1 (and its substages), Metaphase -1, Anaphase -1 , Telophase -1, Metaphase - 2, Anapahse -2 and Telophase -2 (Fig. 1). The chromosomes behaved normally and the meiotic process in these individuals was judged normal [34, 35]. Upon treatment with different concentrations of aqueous extract of $T$. vogelii, the major meiotic chromosome abnormalities noted were Bridges, laggards, vagrant chromosomes, sticky chromosomes, chromosome breakages, and disturbed Metaphases and Anaphases (multipolar anaphases) (Fig. 2 ). The extract definitely changed the microenvironment of the germ cells thereby inducing the formation of these chromosomal abnormalities. The DNA repair mechanism known to act to stabilize the cell could have failed because of the change of the micro internal environments of the cells [36]. The bioactive substances in the extract either directly or indirectly inhibited the action of the DNA repair system. This study therefore showed that treatment with aqueous leaf extract of $T$. vogelii affected the meiotic process in Z. variegatus. These cytogenotoxic abnormalities are known to lead to reduced fertility of the carrier and often lead to genetically, physiologically and biochemically imbalanced offspring. Stickiness is an irreversible chromosome abnormality that leads to cell death [37-39].

A total 743 cells were scored for meiotic chromosome abnormalities and the data collected is shown in Table 1. This table revealed that the different concentrations of aqueous leaf extract of $T$. vogelii induced cytogenotoxic abnormalities in the meiotic chromosomes of $Z$. variegatus. The occurrence of meiotic abnormalities were significantly more prominent $(\mathrm{p}>0.05)$ in the $10 \mu \mathrm{g} / \mathrm{ml}$ of the aqueous leaf extract indicating that the frequency of abnormalities increased with increase in concentration of extract (Fig. 3). The lowest frequency $(0.00 \%)$ was observed for the control while the highest frequency of meiotic abnormalities $(20.48 \%)$ was induced by the $10 \mu \mathrm{g} / \mathrm{ml}$ extract. Disturbed Metaphases and Anaphases occurred least and sticky chromosomes occurred most when germ line cells of $Z$. variegatus were treated with $10 \mu \mathrm{g} / \mathrm{ml}$ extract. The frequencies of these meiotic chromosome abnormalities occurred in the series: Sticky chromosomes > Laggards $>$ Bridge formation $>$ Chromosome loss $>$ chromosome breaks $>$ vagrant chromosomes $>$ disturbed Metaphases $\&$ Anaphases $>$ Bipolar $=$ Tetra-polar Anaphases $($ Table 1). The present study therefore revealed that leaf extract of $T$. vogelii possesses bioactive substances that can induce significant cytogenotoxic effects in the germ line cells of the pest grasshopper Z. variegatus.

\section{CONCLUSIONS}

Aqueous leaf extract of Tephrosia vogelii induced meiotic chromosome abnormalities in the pest grasshopper Zonocerus variegatus. The types of chromosomal abnormalities induced by the extract suggest that it could have potentials for inducing infertility in this grasshopper. Considering the above results, the leaves of $T$. vogelii could be a good source of active ingredients that could be used in the preparation of bio-insecticides against pest grasshoppers.

\section{ACKNOWLEDGEMENTS}

The authors are grateful to the Head of Department (HOD), Department of Biological Sciences, Faculty of Science in The University of Bamenda and the HOD, Department of Animal Biology, Faculty of Science, the University of Dschang, for laboratory space.

\section{Conflicts of interest}

There is no conflict of interest as regard to this work and publishing the article.

Table-1: Meiotic chromosome abnormalities recorded on treatment of $Z$. variegatus individuals with different concentrations of $T$. vogelii aqueous leaf extract

\begin{tabular}{|c|c|c|c|c|c|c|c|c|c|c|c|}
\hline 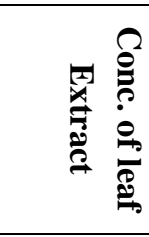 & 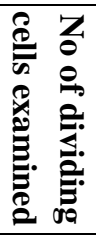 & 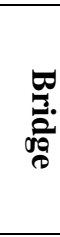 & 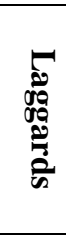 & 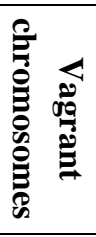 & 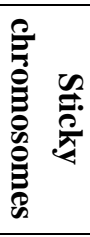 & 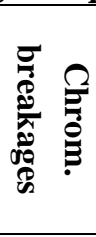 & 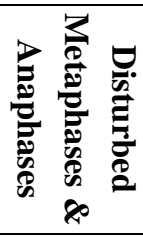 & 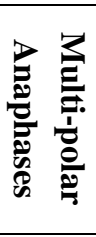 & 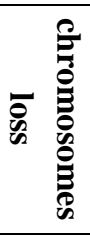 & 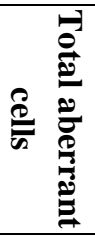 & क \\
\hline $0 \mu \mathrm{g} / \mathrm{ml}$ & 162 & 0 & 0 & 0 & 0 & 0 & 0 & 0 & 0 & 0 & 0 \\
\hline $5 \mu / \mathrm{ml}$ & 288 & 5 & 7 & 0 & 12 & 0 & 0 & 0 & 0 & 24 & 8.33 \\
\hline $10 \mu \mathrm{g} / \mathrm{ml}$ & 293 & 9 & 13 & 4 & 19 & 5 & 2 & 2 & 6 & 60 & 20.48 \\
\hline Total & 743 & 14 & 20 & 4 & 31 & 5 & 2 & 2 & 6 & 86 & 11.58 \\
\hline
\end{tabular}




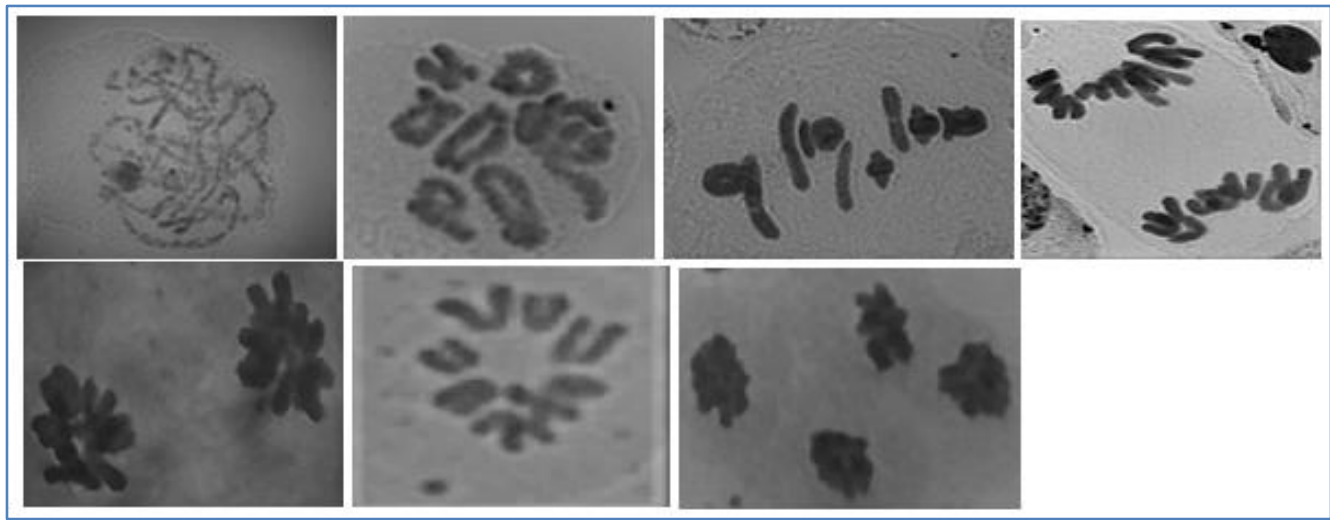

Fig-1: Z. variegatus cells with normal meiotic chromosomes (Control): A = Zygotene (Prophase -1); B = Diplotene (Prophase-1); $\mathrm{C}=$ Metaphase -1 (Side view); D = Anaphase -1; E = Telophase -1;

F = Metaphase -2; $\mathbf{G}=$ Anaphase $-2 ; \mathbf{H}=$ Telophase -2.

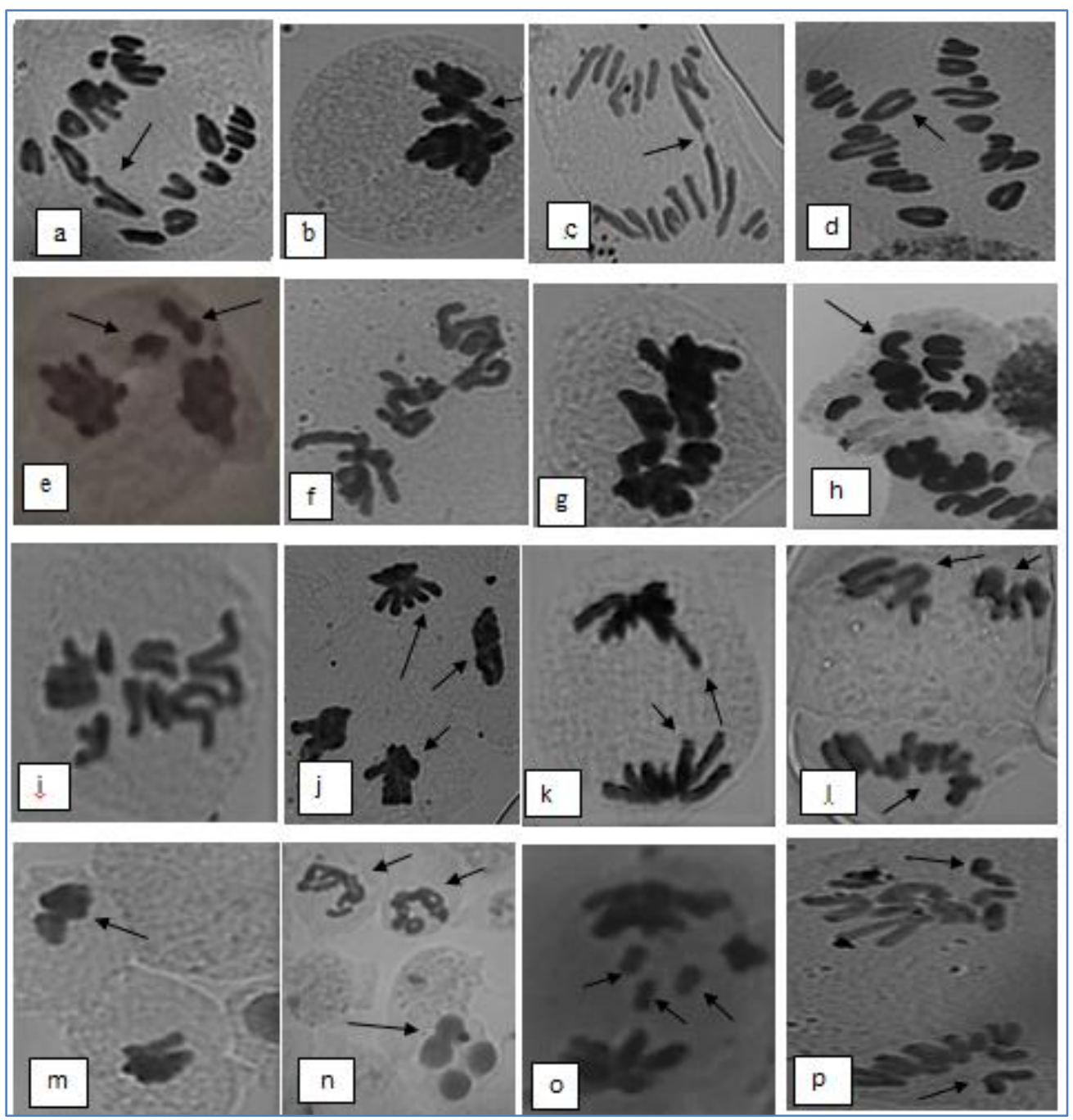

Fig-2: Aberrant meiotic chromosomes in $Z$. variegatus cells treated with aqueous leaf extract of

T. vogelii. a) - arrow indicating Anaphase $\mathbf{- 1}$ bridge; b) arrow indicating Telophase bridge; c) arrow indicating Anaphase -1 pseudo-bridge; d) arrow indicating Anaphase - 1 laggard; e) arrow indicating Telophase -1 laggards; f) disturbed and sticky metaphase -1; g) Sticky Metaphase - 1; h) long arrow indicating sticky Anaphase -1 \& short arrow indicating sticky Metaphase -1; i) disturbed Anaphase -1; j) long arrow indicating Telophase -2 laggards \& short arrow indicating sticky Telophase -2; k) Anaphase-1 with loss of chromosomes; l) arrows indication three poles in the cell (tri-polar Anaphase -2); m) arrow indicating bi-nucleate cell; n) long arrow indicating tetra-nucleate cell \& short arrow indicating sticky diakinesis; o) arrow indicating chromosome breaks; p) arrow indicating vagrant chromosome at Anaphase -1. 


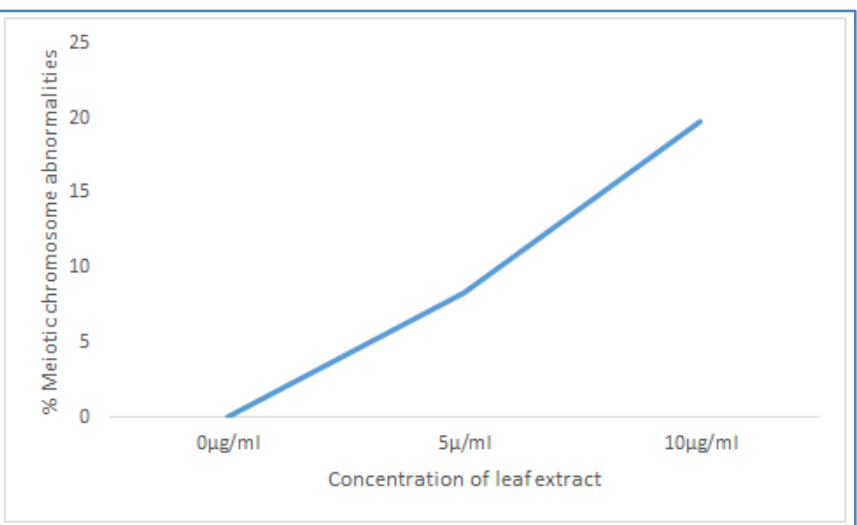

Fig-3: Relationship between different concentrations of aqueous leaf extract of $T$. vogelii and meiotic chromosome abnormalities induced in Z. variegatus germ line

\section{REFERENCES}

1. Idowu AB, Akinsete A. The attraction of Zonocerus variegatus (Orthoptera: Pyrgomorphidae) to different types of lure. Revista de Biologia Tropical, 49(2): $673-678$.

2. Modder W 1994. Control of the variegated grasshopper Zonocerus variegatus L. on cassava. African Crop Science Journal. 2001; 2(4): 391-406.

3. Kekeunou S, Weise S, Messi J, Tamò M. Farmers' perception on the importance of variegated grasshopper (Zonocerus variegatus) (L.) in the agricultural production systems of the humid forest zone of Southern Cameroon. Journal of Ethnobiology and Ethnomedicine. 2006; 2 (17).

4. Mansray A, Sandufu AJ, Samura AE, Massaquoi FB, Quee DD, Fomba SN. Cassava genotype evaluation for grasshopper Zonocerus variegatus susceptibility in the Southern Sierra Leone. International Journal of Agriculture and Forestry. 2012; 2(6): 294-299

5. Kekeunou S, Prombo C, Tamasse JL. Prevalence and abundance of Charletonia sp (Acari: Erythracidae) in Zonocerus variegatus (Linn. 1758) (Othroptera: Pyrgomorphidae) populations in the humid forest zone of southern Cameroon. Bulgarian Journal of Agricultural Science. 2015; 21: 372 377.

6. Agwu JE, Odo GE, Oloto JC, Uwagbae M. Effects of Cypermethrin on the biochemical profile of the haemolymph of African pest grasshopper Zonocerus variegatus (Linn.). Internationl Journal of Biomaterials Science and Engineering. 2016; 3(2): $15-19$.

7. Douro-Kpindou OK, Godonou I, Houssou A, Lomer CJ, Shah P. Control of Zonocerus variegatus by low ultra-low volume application of an oil formulation of Matarhizium flavoviride conidia. Biocontrol Science and Technology. 1995; 5(1): 131 - 139.

8. Fagade OE, Balogun SA, Lomer CJ. Microbial control of caged populations of Zonocerus variegatus using Beauveria bassiana and
Metarhizium sp. African Journal of Biotechnology. 2005; 4(1): 113 - 116

9. Kekeunou S, Fondjo JA, Akono-Ntonga P, Missoup $\mathrm{AD}$, Fiemapong AR. Prévalence et abondance de Charletonia cameroonensis Haitlinger \& Kekeunou 2014 (Acari: Erythraeidae) parasite de Zonocerus variegatus (Linnaeus 1758)(Orthoptera: Pyrgomorphidae) dans la zone côtière du Cameroun. Journal of Applied Biosciences. 2016;104(1):9965-74.

10. Mugerwa J D. Control of the variegated grasshopper Zonocerus variegatus in Masaka and Rakai District of Uganda. National Agricultural Research Organisation, Agricultural Research Service, Uganda. 1991.

11. Isman, M.B. Botanical Insecticides: For Richer, for Poorer. Pest Management Science. 2008; 64, 8-11.

12. Adebayo T A, Olaniran AO, Akanbi W B. Control of insect pests of Cowpea in the filed with Allelochems from Tephrosia vogelii and Petivera alliacea in Southern Guinea Savannah of Nigeria. Agricultural Journal. 2007; 2(3): 365 - 369.

13. Kamanula J, Sileshi GW, Belmain SR, Sola P, Mvumi BM, Nyirenda GK, Nyirenda SP, Stevenson PC. Farmers' insect pest management practices and pesticidal plant use in the protection of stored maize and beans in Southern Africa. International Journal of Pest Management. 2010 Oct 29;57(1):41-9.

14. Hernández-Moreno D, Soffers A E, Falke HE, Rietjens I M, Murk A J. Consumer and farmer safety evaluation of application of botanical pesticides in black pepper crop protection. Food and Chemical Toxicology. 2013; 56: 483-490.

15. Grzywacz D, Stevenson P C, Mushobozi W L, Belmain S, Wilson $\mathrm{K}$. The use of indigenous ecological resources for pest control in Africa. Food Science. 2014. 6: 71-86.

16. Sola P, Mvumi BM, Mponda O, Kamanula JF, Nyirenda SP, Belmain SR, Stevenson PC. Botanical pesticide production, trade and regulatory mechanisms in Sub-Saharan Africa: Making a case 
for plant-based pesticidal products. Food Security. 2014; 6: 369-384.

17. Mkenda P, Mwanauta R, Stevenson PC, Ndakidemi $\mathrm{P}$, Mtei K, Belmain SR. Field margin weeds provide economically viable and environmentally benign pest control compared to synthetic pesticides. PloS One. 2015; 10, e0143530

18. Stevenson PC, Belmainn SR. Tephrosia vogelii: a pesticide of the future for African farming. Boletin SEEA N02. 2017; www.seea.es

19. Stevenson PC, Kite GC, Lewis GP, Forest F, Nyirenda SP, Belmain SR, Sileshi GW, Veitch NC. Distinct chemotypes of Tephrosia vogelii and implications for their use in pest control and soil enrichment. Phytochemistry. 2012 Jun 1;78:135-46.

20. Belmain SR, Amoah BA, Nyirenda SP, Kamanula JF, Stevenson PL. Highly variable insect control efficacy of Tephrosia vogelii chemotypes. Journal of Agricultural and Food Chemistry. 2012; 60(40): $10055-10063$.

21. Adebayo, T.A. Efficacy of mixture formulations of synthetics and botanical insecticides in control of insect pests of Okra and Cowpea Ph.D. thesis Ladoke Akintola University Of technology. Ogbomoso, Nigeria. 2003; $154-169$.

22. Matovu H, Olila D. Acaricidal activity of Tephrosia vogelii extracts on nymph and adult ticks. Int J Trop Med. 2007;2(3):83-8.

23. Mkenda PA, Mtei K, Ndakidemi PA. Pesticidal efficacy of Tephrosia vogelii and Tithonia diversifolia against field insect pests of common beans [Phaseolus vulgaris L.] within African farming communities. African Journal of Applied Agricultural Sciences and Technologie. 2014; 2 (1): 9-26.

24. Stoll G. Natural crop protection in the Tropics. Margraf Verlag. 2000; 376.

25. Seino RA, Akongnui T, Dongmo BN, Manjeli Y. Karyotype and meiosis studies in Oxycatantops spissus (Walker) (Orthoptera: Acrididae). Int. J. Biol. Chem. Sci. 2008; 2(2): 168-174

26. Matthews G, Wiles T, Baleguel P. A survey of pesticide application in Cameroon. Crop Protection. 2003; 22(5):707-714.

27. Mahob RJ, Ndoumbè-Nkeng M, Ten Hoopen GM, Dibog L, Nyassé S, Rutherford M, Mbenoun M, Babin R, Amang A, Mbang J, Yede, Bilong Bilong $\mathrm{CF}$. Pesticides use in cocoa sector in Cameroon: characterization of supply source, nature of actives ingredients, fashion and reasons for their utilization. Int. J. Biol. Chem. Sci. 2014; 8(5): 1976-1989.
28. Aktar MW, Sengupta D, Chowdhury A. Impact of pesticides use in agriculture: their benefits and hazards. Interdiscip. Toxicol. 2009; 2(1): 1-12.

29. Bertrand PG, Ahmed HAM, Ngwafor R, Frazzoli C. Toxico vigilance Systems and Practices in Africa. Toxics. 2016; 4:13.

30. Nicolopoulou-Stamati P, Maipas S, Kotampasi C, Stamatis P, Hens L. Chemical pesticides and human health: the urgent need for a new concept in agriculture. Frontiers in public health. $2016 \mathrm{Jul}$ $18 ; 4: 148$

31. Koona P, Dorn S. Extracts from Tephrosia vogelii for the protection of stored legume seeds against damage by three bruchid species. Annals of applied biology. 2005 Aug;147(1):43-8.

32. Igogo JM, Ogendo JO, Kariuki ST, Otaye DO. Insecticidal, antifeedant and repellent effects of Tephrosia vogelii Hook. and Lantana camara L. aqueous crude extracts against golden flea beetle, Aphthona whitfieldi Bryant in Jatropha, Jatropha curcas L. Biopesticides International. 2011;7(2):93-103.

33. Faluyi JO, Olorode O. Mitotic chromosome studies in the nymphal and adult populations of Zonocerus variegatus L.(Orthoptera: Pyrgomorphidae). Revue de zoologie africaine (1974). 1988;102(4):475-80.

34. Faluyi JO, Olorode O. Mitotic chromosome studies in the nymphal and adult populations of Zonocerus variegatus L.(Orthoptera: Pyrgomorphidae). Revue de zoologie africaine (1974). 1988;102(4):475-80.

35. Bomblies K, Higgins JD, Yant L. Meiosis evolves: adaptation to external and internal environments. New Phytologist. 2015 Oct;208(2):306-23.

36. Cebulska-Wasiewska A, Panek A, Zabinski Z, Moszczynski P, Au WW. Occupational expose of mecury vapour on genotoxicity and DNA repair. Mutat. Res. Genet. Toxicol. 2005; 586: $102-114$.

37. Singhal VK and Kumar P. Impact of cytomixis on meiosis, pollen viability and pollen size in wild populations of Himalayan poppy (Meconopsis aculeata Royle). Journal of Biosciences. 2008; 33(3): 371-380

38. Datta S, Singh J, Singh S, Singh S. Assessment of genotoxic effect of pesticide and vermicompost soil with Allium cepa test. Sustainable Environment Research. 2018; 28: 171-178.

39. Seino RA, Dongmo TI, Chifon RN and Shambo DN. Possible Cytogenetic Effect of Capsicum frutescens (Solanaceae) Extracts on Meiosis in the Grasshopper Taphronota thaelephora Stal. (Orthoptera: Pyrgomorphidae). Enliven: J Genet Mol Cell Biol. 2014; 1(1): 002. 